\title{
Mitochondrial DNA mutations in human colonic crypt stem cells
}

\author{
Robert W. Taylor, ${ }^{1}$ Martin J. Barron, ${ }^{1}$ Gillian M. Borthwick, ${ }^{1}$ Amy Gospel, ${ }^{1}$ \\ Patrick F. Chinnery, ${ }^{1}$ David C. Samuels, ${ }^{2}$ Geoffrey A. Taylor, ${ }^{3}$ Stefan M. Plusa, ${ }^{4}$ \\ Stephanie J. Needham, ${ }^{5}$ Laura C. Greaves, ${ }^{1,6}$ Thomas B.L. Kirkwood, ${ }^{6}$ \\ and Douglass M. Turnbull ${ }^{1}$
}

\author{
${ }^{1}$ Department of Neurology, and \\ ${ }^{2}$ Department of Mathematics, The Medical School, University of Newcastle upon Tyne, Newcastle upon Tyne, \\ United Kingdom \\ ${ }^{3}$ Medical Research Council Development Centre for Brain Ageing, University of Newcastle upon Tyne, Newcastle upon Tyne, \\ United Kingdom \\ ${ }^{4}$ Department of Surgery, \\ ${ }^{5}$ Department of Pathology, and \\ ${ }^{6}$ Department of Gerontology, The Medical School, University of Newcastle upon Tyne, Newcastle upon Tyne, United Kingdom
}

\begin{abstract}
The mitochondrial genome encodes 13 essential subunits of the respiratory chain and has remarkable genetics based on uniparental inheritance. Within human populations, the mitochondrial genome has a high rate of sequence divergence with multiple polymorphic variants and thus has played a major role in examining the evolutionary history of our species. In recent years it has also become apparent that pathogenic mitochondrial DNA (mtDNA) mutations play an important role in neurological and other diseases. Patients harbor many different mtDNA mutations, some of which are mtDNA mutations, some of which are inherited, but others that seem to be sporadic. It has also been suggested that mtDNA mutations play a role in aging and cancer, but the evidence for a causative role in these conditions is less clear. The accumulated data would suggest, however, that mtDNA mutations occur on a frequent basis. In this article we describe a new phenomenon: the accumulation of mtDNA mutations in human colonic crypt stem cells that result in a significant biochemical defect in their progeny. These studies have important consequences not only for understanding of the finding of mtDNA mutations in aging tissues and tumors, but also for determining the frequency of mtDNA mutations within a cell.
\end{abstract}

J. Clin. Invest. 112:1351-1360 (2003). doi: 10.1172/JCI200319435.

\section{Introduction}

Mitochondria are essential intracellular organelles required for oxidative phosphorylation. One of the unique aspects of mitochondria is the dual genetic control of mitochondrial biosynthesis. Mitochondria contain their own genome, mitochondrial DNA (mtDNA), which is a small $(16.5 \mathrm{~kb})$, self-replicating DNA mole-

Received for publication July 9, 2003, and accepted in revised form September 9, 2003.

Address correspondence to: D.M. Turnbull, Mitochondrial Research Group, School of Neurology, Neurobiology and Psychiatry, The Medical School, University of Newcastle upon Tyne, Newcastle upon Tyne NE2 4HH, United Kingdom. Phone: 44-191-2228334; Fax: 44-191-2228553;

E-mail: d.m.turnbull@ncl.ac.uk.

David C. Samuels' present address is: Virginia Bioinformatics Institute, Virginia Polytechnical Institute and State University, Blacksburg, Virginia 24061, USA.

Robert W. Taylor and Martin J. Barron contributed equally to this work.

Conflict of interest: The authors have declared that no conflict of interest exists.

Nonstandard abbreviations used: mitochondrial DNA (mtDNA); ribosomal RNA (rRNA); transfer RNA (tRNA); succinate dehydrogenase (SDH). cule present in multiple copies in the mitochondrial matrix. This genome encodes 13 essential proteins of the mitochondrial respiratory chain as well as 2 ribosomal RNA (rRNA) and 22 transfer RNA (tRNA) genes required for intramitochondrial synthesis of proteins. All the other mitochondrial proteins are nuclear encoded and transported into the mitochondria. Inherited abnormalities of the mitochondrial genome are now increasingly recognized as important causes of disease (1). These mutations can affect all copies of the mitochondrial genome within a cell - termed homoplasmy - or there may be a mixture of mutated and wild-type genomes in the same cell - heteroplasmy (2). Since mitochondria contain multiple mtDNA copies and cells may contain hundreds or thousands of mitochondria, in the presence of heteroplasmy high levels of mutated mtDNA usually must be present within an individual cell before a defect of oxidative phosphorylation is apparent (3).

In addition to inherited mtDNA mutations, sporadic mtDNA mutations causing disease are common, and it has been noted for some time that mtDNA mutations occur with aging in postmitotic tissues (4-7). Both these events suggest that mtDNA mutation is a fairly 
frequent event, a view supported by the high sequence divergence within the human population. It is suspected that the high mutation rate is due to an environment in which there is a high production of free radicals by the respiratory chain, compounded by limited repair of this genome compared with nuclear DNA. Even if mutations occur at high frequency, the mechanism by which these mutations accumulate to high levels in individual cells remains uncertain, but mathematical models would favor clonal expansion by random genetic drift $(8,9)$.

Previous work on somatic mtDNA mutations has concentrated on the observations in postmitotic tissues, such as muscle and the CNS, since these tissues are predominantly involved in patients with mtDNA disease. Even in these tissues, systematic studies of the nature and incidence of mutations is limited. A small number of reports cite the accumulation of mtDNA mutations in replicative cells $(6,10)$. An important question in mitochondrial genetics is whether there is evidence of mtDNA mutations in stem cells, and if so, do these mutations accumulate to levels sufficient to result in a biochemical defect. If so, this could have profound implications for our understanding of the potential importance of these mutations in aging and cancer. To investigate the existence of mtDNA mutations in stem cells, we decided to study colonic crypt stem cells. Colonic crypt stem cells are present at the crypt base, and thus all the cells within the crypt must be derived from these stem cells. Thus, we would not have to isolate individual stem cells to look for mtDNA mutations, but could in theory study their progeny. While there is uncertainty about the number of stem cells within human colonic crypts, studies in mice suggest that crypts are maintained by small numbers of stem cells (11). For example, in chimeric mouse strains a single crypt often shows evidence of clonality in adult mice, suggesting that the majority of cells within an individual crypt are the progeny of a single stem cell (12). Studies in humans are much more difficult because strategies that directly mark cell fates, such as aggregation chimeras and mutagenesis, are impractical in humans (13); however, current evidence would support that the situation is similar to mice.

\section{Methods}

Patients and colonic samples. Colons were collected from 16 patients with no family history of colon cancer (age range: $50-80$ years) undergoing resection for colonic tumors. Each sample of normal colonic mucosa was collected at a distance of at least $12 \mathrm{~cm}$ from the edge of the tumor. We also obtained colonoscopy biopsies from 12 individuals undergoing investigation of altered bowel function in which no pathology was found (age range: $36-78$ years).

Histochemistry. Colon samples were mounted for sectioning and frozen in isopentane previously cooled to $-160^{\circ} \mathrm{C}$ in liquid nitrogen. Standard H\&E histology was performed on $12-\mu \mathrm{m}$ sections. A dual histochemical assay was used to determine the respiratory activity of the crypts. Cryostat sections $(12 \mu \mathrm{m})$ were first incubated in cytochrome $c$ oxidase medium $(100 \mu \mathrm{M}$ cytochrome $c, 4 \mathrm{mM}$ diaminobenzidine tetrahydrochloride, and $20 \mu \mathrm{g} / \mathrm{ml}$ catalase in $0.2 \mathrm{M}$ phosphate buffer, $\mathrm{pH} 7.0)$ at $37^{\circ} \mathrm{C}$ for 50 minutes. Sections were then washed in PBS $(3 \times 5$ minutes $)$ and incubated in succinate dehydrogenase $(\mathrm{SDH})$ medium $(130 \mathrm{mM}$ sodium succinate, $200 \mu \mathrm{M}$ phenazine methosulphate, $1 \mathrm{mM}$ sodium azide, $1.5 \mathrm{mM}$ nitroblue tetrazolium in $0.2 \mathrm{M}$ phosphate buffer, $\mathrm{pH} 7.0$ ) at $37^{\circ} \mathrm{C}$ for $40 \mathrm{~min}$ utes. Sections were washed in PBS, pH $7.4(3 \times 5$ minutes), dehydrated in a graded ethanol series $(70 \%, 95 \%$, $2 \times 100 \%$ ), cleared in Histoclear (National Diagnostics, Atlanta, Georgia, USA), and mounted in DPX (BDH Laboratory Supplies, Poole, United Kingdom).

The percentage of cytochrome $c$ oxidase-deficient crypts was calculated from transverse sections counted at several different levels, and approximately 100 crypts were evaluated at each level. Only crypts that were more than $50 \%$ cytochrome $c$ oxidase deficient were included.

Immunocytochemistry. Immunocytochemistry was performed on $10-\mu \mathrm{m}$ cryostat sections air-dried at room temperature for 1 hour. The sections were fixed in $4 \%$ paraformaldehyde in $0.1 \mathrm{M}$ phosphate buffer for 10 minutes, followed by rinsing in distilled water and then PBS containing $0.1 \%$ Triton $\mathrm{X}-100$ for 10 minutes. The sections were further permeabilized in a graded $(70 \%$, $95 \%, 100 \% \mathrm{vol} / \mathrm{vol}$ ) methanol series over a period of 1 hour. Endogenous peroxidase activity was quenched at this stage by the addition of hydrogen peroxide $(0.3 \%$ $\mathrm{vol} / \mathrm{vol})$ to the $95 \%(\mathrm{vol} / \mathrm{vol})$ methanol. The sections were rinsed in PBS, then incubated with anticytochrome $c$ oxidase subunit Ab (anti-subunit I, 2 $\mu \mathrm{g} / \mathrm{ml}$, anti-subunit II and IV, $5 \mu \mathrm{g} / \mathrm{ml}$; Molecular Probes Inc., Eugene, Oregon, USA) diluted in 4\% BSA in PBS for 1 hour at room temperature. Following three washes in PBS, the sections were incubated with a peroxidase-conjugated $\mathrm{Ab}$ (rabbit anti-mouse Ig's, 50 $\mu \mathrm{g} / \mathrm{ml}$; DAKO Ltd., Ely, United Kingdom) for 1 hour at room temperature. Following washing in PBS, peroxidase activity was detected by incubating in $1.4 \mathrm{mM}$ 3,3'-diaminobenzadine tetrahydrochloride and $0.01 \%$ (vol/vol) hydrogen peroxide in $0.1 \mathrm{M}$ phosphate buffer, $\mathrm{pH} 7.4$, for 5 minutes at room temperature.

Three-dimensional reconstruction of colonic crypts. Threedimensional reconstruction of crypts was performed using KS300 3D software (Imaging Associates Ltd., Thame, United Kingdom) on digital images of 59 serial sections $(8 \mu \mathrm{m})$ reacted for cytochrome $c$ oxidase and SDH histochemistry.

Isolation of total DNA from individual and partial crypts. Fresh frozen sections $(20 \mu \mathrm{m})$ of colon were mounted on polyethylenenaphthalate slides (Leica Microsystems UK Ltd., Milton Keynes, United Kingdom). Samples were subjected to dual histochemistry as described above and air-dried after dehydration. Single and partial crypts were cut into sterile $0.5-\mathrm{ml}$ PCR tubes using a Leica laser microdissection system. Following centrifugation $(7,000 \mathrm{~g}$ for 10 minutes), the crypt was lysed 
in $10 \mu \mathrm{l}$ of cell lysis buffer $(50 \mathrm{mM}$ Tris- $\mathrm{HCl}, \mathrm{pH} 8.5$, $1 \mathrm{mM}$ EDTA, $0.5 \%$ Tween- $20,200 \mathrm{ng} / \mathrm{ml}$ proteinase $\mathrm{K}$ ) at $55^{\circ} \mathrm{C}$ for 2 hours and then $95^{\circ} \mathrm{C}$ for 10 minutes to denature the proteinase $\mathrm{K}$.

Real-time PCR analysis of $m t D N A$. A quantitative realtime PCR approach employing fluorogenic probes was used to quantify the amount of mtDNA in two different regions of the mitochondrial genome, one that is rarely deleted in patients and aging (ND1 gene) and one that is frequently deleted (ND4 gene). PCR primers and fluorogenic probes (Applied Biosystems, Warrington, United Kingdom) for regions of $N D 1$ (forward primer, L3485-3504; reverse primer, H3553-3532; probe, L3506-3529), and ND4 (forward primer, L12087-12109; reverse primer, H12170-12140; probe, L12111-12138) were synthesized, and $5 \mu \mathrm{l}$ of DNA lysate from a single crypt was amplified separately with each of the ND1 and ND4 primer/probe combinations as described previously (14).

Sequencing of mtDNA from individual colonic crypts. The entire sequence of the mitochondrial genome from microdissected crypts was determined using the singlecell lysate (see above) as the DNA template and a twostage amplification protocol essentially as described previously (15). The primary PCR reactions involved amplification of the mitochondrial genome in 11 fragments of approximately $2 \mathrm{~kb}$ using a series of overlapping primer pairs. These initial large PCR reaction products decrease the risk of amplifying pseudogenes when extracting DNA from small quantities of DNA (16). All PCR amplifications were performed in a $50 \mu \mathrm{l}$ volume containing $1 \times$ PCR buffer $(10 \mathrm{mM}$ Tris- $\mathrm{HCl}$, $\mathrm{pH}$ 8.3, $1.5 \mathrm{mM} \mathrm{MgCl}_{2}, 50 \mathrm{mM} \mathrm{KCl}, 0.001 \% \mathrm{wt} /$ vol gelatin), $0.2 \mathrm{mM}$ dNTPs, $0.6 \mu \mathrm{M}$ primers, $1 \mathrm{U}$ AmpliTaq Gold DNA polymerase (Applied Biosystems), and $1 \mu \mathrm{l}$ single-cell lysate. Reaction conditions were $94^{\circ} \mathrm{C}$ for 12 minutes and 38 cycles of $94^{\circ} \mathrm{C}$ for 1 minute, $60^{\circ} \mathrm{C}$ for 1 minute, and $72^{\circ} \mathrm{C}$ for 2 minutes. The final extension was for 8 minutes.

The secondary PCR reactions involved amplification of the primary PCR products with 28 primer pairs specifically to generate overlapping fragments of between 600-700 bp that span the entire sequence of the human mitochondrial genome (15). To facilitate the direct sequencing of PCR-amplified products, all primer pairs are tagged with M13 sequence and designed to anneal optimally at $58^{\circ} \mathrm{C}$. All reactions proceeded for 30 cycles and used $2 \mu \mathrm{l}$ of primary reaction product as DNA template. Samples were subsequently purified to remove unincorporated primers and were directly sequenced using BigDye terminator cycle-sequencing chemistries (Applied Biosystems) on an $\mathrm{ABI} 377$ automated DNA sequencer. The sequences obtained were compared with the revised Cambridge reference sequence using Sequence Navigator and Factura software (Applied Biosystems).

Individual mutations were confirmed in all instances by repeating the second-round PCR and resequencing the product. For some products, the mutation was con- firmed by restriction fragment-length polymorphism analysis using restriction enzymes that specifically recognized the mutation. Finally, to ensure mutations were not introduced during PCR, we microdissected two separate segments of the same cytochrome $c$ oxidase-deficient crypt. Sequencing of the entire mitochondrial genome from both partial crypts revealed not only the presence of an identical mtDNA mutation, but no other detectable sequence changes.

\section{Results}

Respiratory chain deficiency in colonic crypts and crypt stem cells. Cells deficient in cytochrome $c$ oxidase but with normal SDH activity are excellent biomarkers of mtDNA defects (17). We wished to determine if such cells were present in colonic epithelium and prepared frozen sections of normal colonic epithelium. The mucosal anatomy was preserved with our procedure for collection and mounting of sections, as shown by the crypt morphology using H\&E (Figure 1, a and b). Some crypts from every patient we examined were cytochrome $c$ oxidase deficient (Figure 1, c-h). To ensure that our techniques were completely specific, we performed control experiments on colonic epithelium using specific inhibitors of mitochondrial enzyme activity (sodium azide for cytochrome $c$ oxidase and sodium malonate for SDH) (Figure 1, i-l). These experiments confirm that the reaction is specific and that our observations reflect a genuine decrease in cytochrome $c$ oxidase activity. We found that these cytochrome $c$ oxidase-deficient crypts were distributed throughout the colon because we examined samples obtained from both right and left hemicolectomy.

In addition to detecting whole crypts showing cytochrome $c$ oxidase deficiency, we observed crypts showing a deficiency of this enzyme in only part of the crypt. To investigate the phenomenon of partial cytochrome $c$ oxidase deficiency further, we serially sectioned $(8 \mu \mathrm{m})$ colonic mucosa transversely and performed 3D reconstruction of the crypts following dual cytochrome $c$ oxidase/SDH histochemistry (Figure 2a). In these crypts there is a ribbon of cytochrome $c$ oxidase-deficient cells within an otherwise normal crypt that is entirely compatible with the view that there are multiple stem cells in some crypts and that what we are observing reflects involvement of one stem cell and its progeny.

We also studied the expression of cytochrome $c$ oxidase subunits I (Figure 2b) and II (both mtDNA encoded) and subunit IV (nuclear encoded) (Figure 2c) in nine patients. In all patients there was an absence of immunoreactivity against subunits I (Figure $2 b$ ) and II in cytochrome $c$ oxidase-deficient crypts. Immunoreactivity against subunit IV was reduced in all cytochrome $c$ oxidase-deficient crypts (Figure 2c), but not decreased to the level seen with subunits I and II.

Mitochondrial genome analysis. To establish if the cytochrome $c$ oxidase deficiency, observed in the colonic crypts was due to mtDNA mutations we identified individual crypts on longitudinal sections and isolated the 
crypt by laser microdissection. We searched for deletions of the major arc of the mitochondrial genome by real-time PCR and for point mutations of mtDNA by sequencing using techniques that have been modified to enable the investigation of single cells $(14,15)$.

Our studies have focused on five patients (age range 69-75 years; cytochrome $c$ oxidase deficient crypts 2.8-27.9\%). Using real-time PCR to screen for mtDNA deletions, we failed to detect any mtDNA deletions in either 40 cytochrome $c$ oxidase-positive or 40 cytochrome $c$ oxidase-deficient crypts. From each patient we then completely sequenced eight cytochrome $c$ oxidase-deficient crypts and four cytochrome $c$ oxidase-positive crypts. For each crypt we compared the sequence to the revised Cambridge reference sequence (18) and the sequence obtained from the other crypts from that patient. We detected numerous mtDNA point mutations in the crypts from these patients in both the heteroplasmic and homoplasmic state (Table 1). In some crypts, we detected only a single mtDNA point mutation, while in others there were multiple mutations (up to four per crypt). Mutations were seen in the cytochrome $c$ oxidase-normal crypts as well as the deficient crypts. In the cytochrome $c$ oxidase-normal crypts, the mutations seen are neutral polymorphisms or mutations that are not predicted to disrupt cytochrome $c$ oxidase deficiency. Such changes include (i) pathogenic mutations (e.g., G15084A; ref. 19) involving genes encoding structural subunits of other respiratory chain complexes (I and III); (ii) mutations that occur at sites unlikely to induce an enzyme defect (e.g., G9985A affects subunit III of cytochrome $c$ oxidase but a

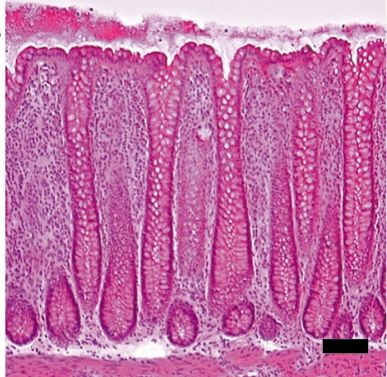

e

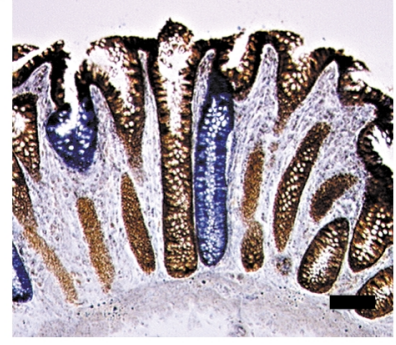

i

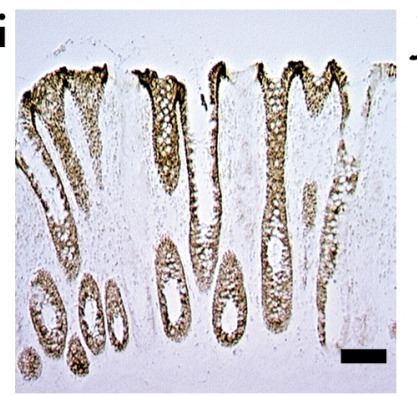

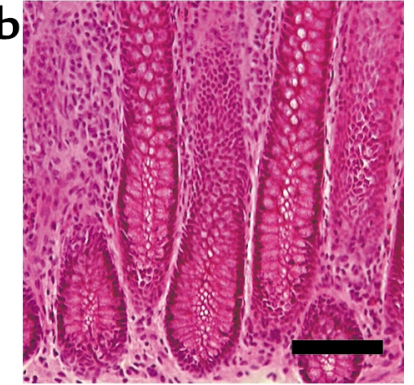
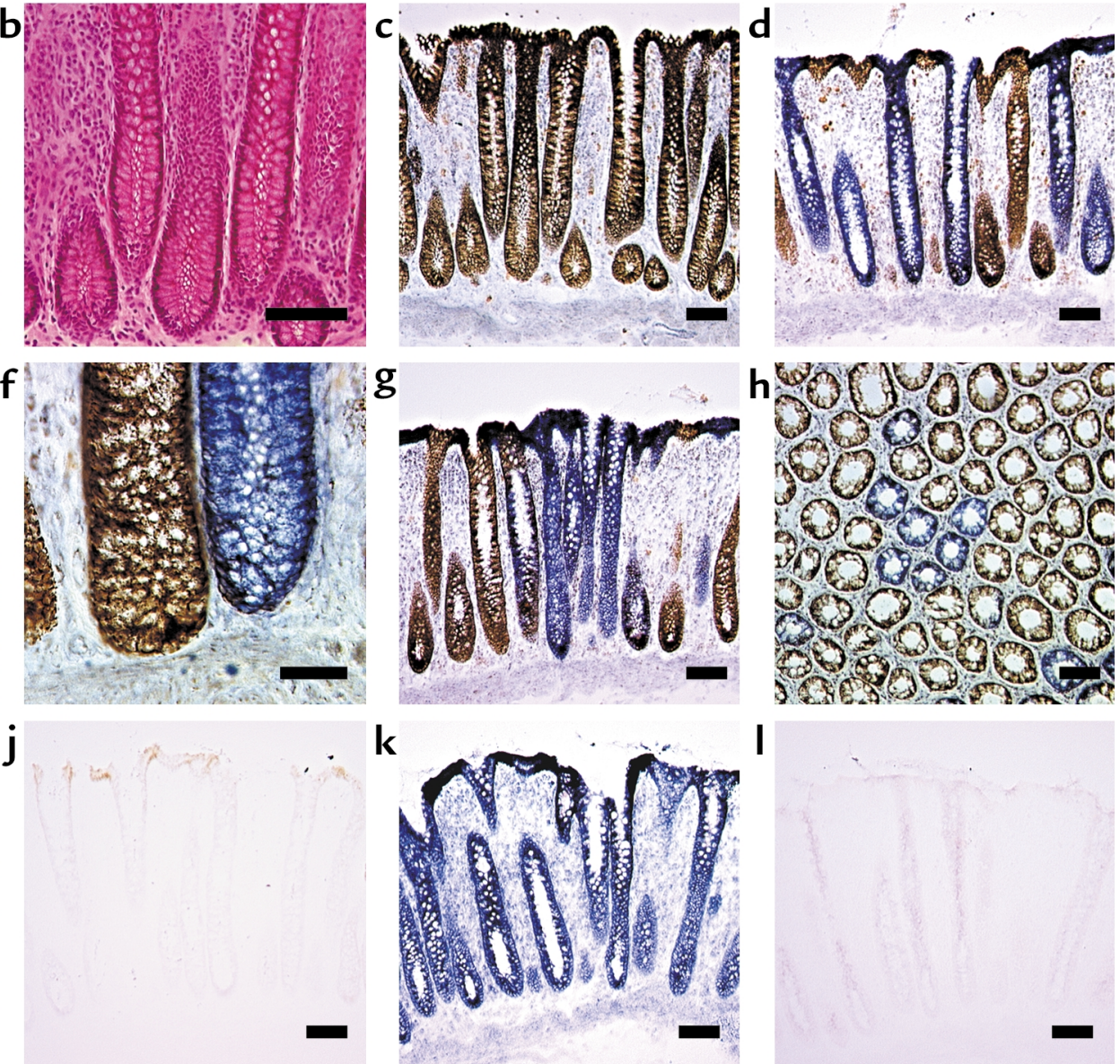

1

\section{Figure 1}

Respiratory chain deficiency in normal human colonic mucosa. (a) H\&E preparations showing normal mucosal structure. Scale bar: 100 $\mu \mathrm{m}$. (b) Higher magnification of a, showing normal crypt structure. Scale bar: $50 \mu \mathrm{m}$. (c) Normal cytochrome $c$ oxidase activity (brown) in colonic crypts following dual cytochrome $c$ oxidase and succinate dehydrogenase histochemistry. Scale bar: $100 \mu$ m. (d) Absence of histochemically detectable cytochrome $c$ oxidase activity in colonic crypts (blue). Note delineation of crypt territories at the luminal surface. Scale bar: $100 \mu \mathrm{m}$. (e) Single cytochrome $c$ oxidase-deficient colonic crypt. Scale bar: $100 \mu \mathrm{m}$. (f) Higher magnification of e, showing crypt base. Scale bar: $20 \mu \mathrm{m}$. (g) Presence of multiple, adjacent cytochrome $c$ oxidase-deficient crypts. Scale bar: $100 \mu \mathrm{m}$. (h) Transverse section showing a similar cluster of cytochrome $c$ oxidase-deficient crypts. Scale bar: $100 \mu \mathrm{m}$. The specificity of the dual cytochrome $c$ oxidase and succinate dehydrogenase histochemical assay was established. (i) Colonic mucosa incubated in standard cytochrome $c$ oxidase medium. (j) Colonic mucosa incubated as i, but in the presence of $2.5 \mathrm{mM}$ sodium azide, a specific inhibitor of cytochrome $c$ oxidase. (k) Colonic mucosa incubated in standard succinate dehydrogenase medium. (I) Colonic mucosa incubated as $\mathbf{k}$, but in the presence of 50 mM sodium malonate, a competitive inhibitor of succinate dehydrogenase. Scale bars: $100 \mu \mathrm{m}(\mathbf{i}-\mathbf{k})$. 
a

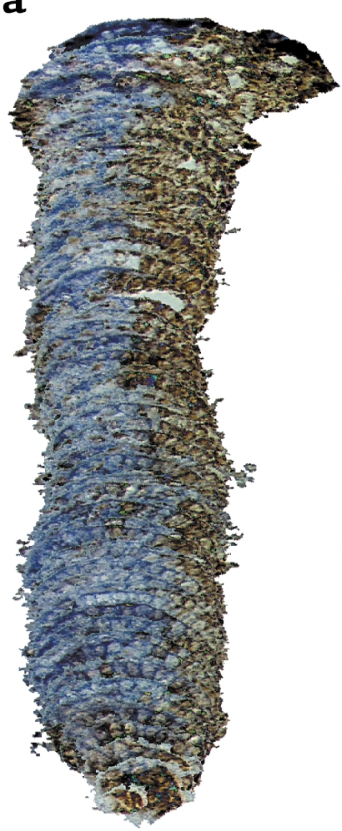

b

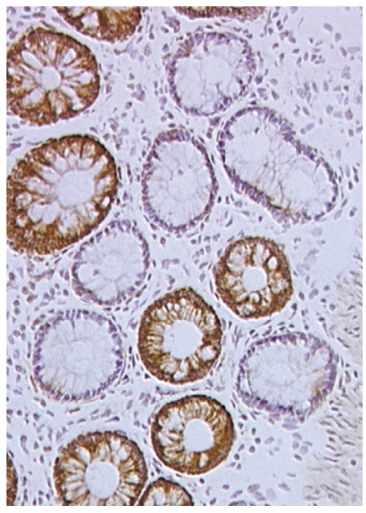

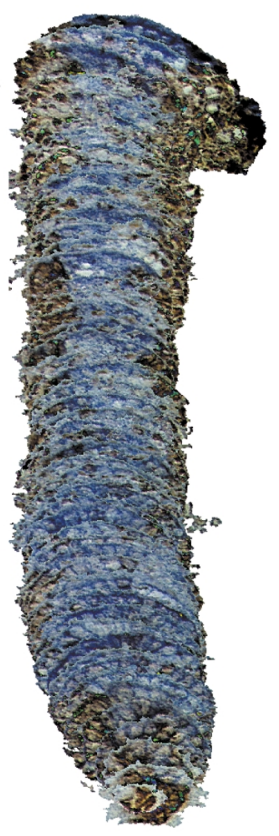
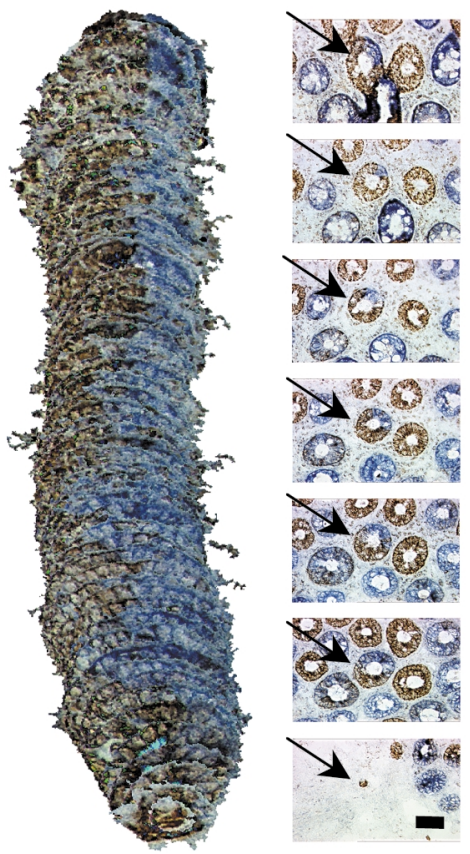

c

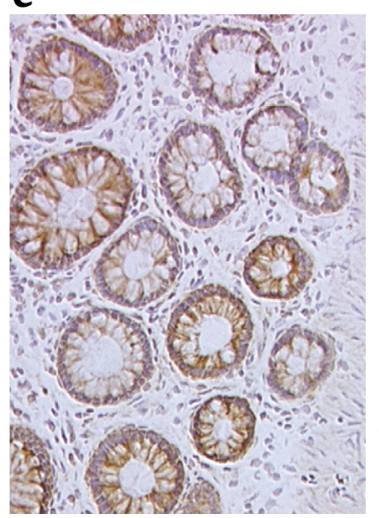

d

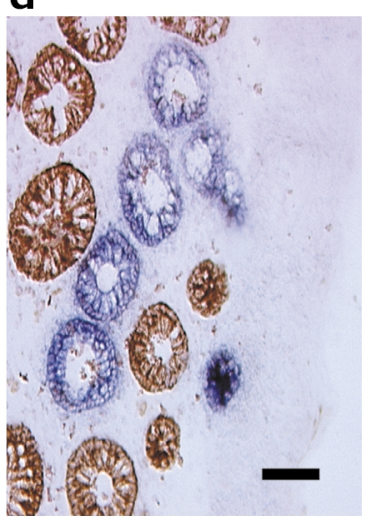

Figure 2

Partial respiratory chain deficiency in some crypts and immunocytochemistry of cytochrome $c$ oxidase deficiency. (a) Reconstructed images were produced from 59 transverse sections $(8 \mu \mathrm{m})$ covering the full thickness of the colonic lamina propria. Representative images of the sections reacted for cytochrome $c$ oxidase and succinate dehydrogenase are shown in the panel on the extreme right, with the reconstructed crypt arrowed. Scale bar: $50 \mu \mathrm{m}$. The position of each image corresponds to the approximate position in the adjacent reconstructed images. The images of the reconstructed colonic crypt are each rotated clockwise through $45^{\circ} \mathrm{C}$ to show a continuous ribbon of cytochrome $c$ oxidase-deficient cells originating at the crypt base. (b-d) Representative serial transverse sections of colonic crypts showing immunoreactivity of cytochrome $c$ oxidase subunit I (b), immunoreactivity of cytochrome $c$ oxidase subunit IV (c), and dual cytochrome $c$ oxidase/succinate dehydrogenase histochemistry (d). Scale bar: $50 \mu \mathrm{m}$ (b-d). alters the penultimate amino acid of this subunit); and (iii) mutations that are present at levels of heteroplasmy that are unlikely to affect mitochondrial protein synthesis (e.g., T10020C within the $t R N A^{G l y}$ gene).

In contrast, in the cytochrome $c$ oxidase-deficient crypts we detected pathogenic mutations, many involving the cytochrome $c$ oxidase subunits. For example one of the mutations (C9537ins) in COIII (Figure 3b) has been reported previously to be pathogenic (20). In another cytochrome $c$ oxidase-deficient crypt from a different patient we also detected a single nucleotide deletion in this same short, poly-C tract (C9537del) that induces a stop codon (Figure 3c). Other mutations include frameshift mutations, stop mutations, or highly conserved amino acid changes within the $C O$ genes (Table 1 ). In some of the crypts in which we did not detect mutations involving the cytochrome $c$ oxidase subunits, we detected high levels of heteroplasmy or even homoplasmic mutations of tRNA or rRNA genes (Table 1).

The majority of mutations we detected were transitions involving $\mathrm{G}$ residues. This is similar to the obser- vation made by Polyak et al. (21) when they performed mtDNA sequencing of human colonic tumors and probably results from $G$ residues being the preferred target for oxidative damage. This would certainly be compatible with the concept that the mutations are acquired and secondary to the reactive oxygen species generated in the mitochondria (22).

Finally, patient 5 harbored two heteroplasmic mutations (G9025A and G9612A) that were present in several crypts (both cytochrome $c$ oxidase positive and deficient). These mutations segregated together with levels varying from $0 \%$ to $100 \%$ within different crypts. It is likely that these are inherited mutations that are segregating through random drift, similar to a recent mouse model of mtDNA heteroplasmy (23).

Mathematical modeling of mtDNA mutation and replication in stem cells. Our observation of mtDNA mutations in individual crypts raises questions as to the mechanism by which these mutations develop in the stem cells. Consequently, we developed a computer model of mtDNA replication and segregation in human colonic crypt stem 
Table 1

Mitochondrial DNA sequence analysis of human colonic crypts

\begin{tabular}{|c|c|c|c|c|c|c|c|}
\hline Patient & Crypt & Mutation & Gene & Mutation status & AA change & Site conservation & Database \\
\hline $1(75 \mathrm{yr})$ & $\begin{array}{l}1+ \\
2+ \\
1- \\
2- \\
2- \\
2- \\
3- \\
3- \\
4- \\
5- \\
5- \\
6- \\
6- \\
6- \\
7- \\
7-\end{array}$ & $\begin{array}{l}\text { G15084A } \\
\text { G6852A } \\
\text { G8154A } \\
\text { G7090A } \\
\text { G7775A } \\
\text { C12390ins } \\
\text { G9774A } \\
\text { A11100G } \\
\text { G2815A } \\
\text { G564A } \\
\text { G7065A } \\
\text { G586A } \\
\text { G1097A } \\
\text { G8572A } \\
\text { T879C } \\
\text { G4788A }\end{array}$ & $\begin{array}{c}\text { cyt b } \\
\text { COI } \\
\text { COII } \\
\text { COI } \\
\text { COII } \\
\text { ND5 } \\
\text { COIII } \\
\text { ND4 } \\
\text { 16S rRNA } \\
\text { D-loop } \\
\text { COI } \\
\text { tRNA Phe } \\
\text { 12S rRNA } \\
\text { ATPase 6 } \\
\text { 12S rRNA } \\
\text { ND2 }\end{array}$ & $\begin{array}{c}\text { heteroplasmic }(60 \%) \\
\text { heteroplasmic }(60 \%) \\
\text { homoplasmic } \\
\text { homoplasmic } \\
\text { heteroplasmic }(70 \%) \\
\text { heteroplasmic }(90 \%) \\
\text { homoplasmic } \\
\text { heteroplasmic }(30 \%) \\
\text { heteroplasmic }(60 \%) \\
\text { heteroplasmic (80\%) } \\
\text { homoplasmic } \\
\text { heteroplasmic (50\%) } \\
\text { homoplasmic } \\
\text { homoplasmic } \\
\text { heteroplasmic }(50 \%) \\
\text { heteroplasmic }(40 \%)\end{array}$ & $\begin{array}{c}\text { Trp-TER } \\
\text { Gly-Ser } \\
\text { Gly-Glu } \\
\text { Trp-TER } \\
\text { Val-Ile } \\
\text { frameshift } \\
\text { Asp-Asn } \\
\text { Glu-Gly } \\
- \\
- \\
\text { Ala-Thr } \\
- \\
- \\
- \\
- \\
\text { Gly-TER }\end{array}$ & $\begin{array}{l}\text { highly conserved } \\
\text { highly conserved } \\
\text { highly conserved } \\
\text { highly conserved } \\
\text { poorly conserved } \\
\text { moderately conserved } \\
\text { highly conserved } \\
\text { highly conserved } \\
\text { highly conserved } \\
- \\
\text { moderately conserved } \\
\text { highly conserved } \\
\text { moderately conserved } \\
\text { highly conserved } \\
\text { highly conserved } \\
\text { highly conserved }\end{array}$ & $\begin{array}{c}\text { not seen } \\
\text { Haplogroup } \mathrm{H} \\
\text { not seen } \\
\text { not seen } \\
\text { not seen } \\
\text { not seen } \\
\text { not seen } \\
\text { not seen } \\
\text { not seen } \\
\text { not seen } \\
\text { not seen } \\
\text { not seen } \\
\text { not seen } \\
\text { Haplogroup } \mathrm{H}, \mathrm{T} \\
\text { not seen } \\
\text { not seen }\end{array}$ \\
\hline $2(76 y r)$ & $\begin{array}{l}1+ \\
1+ \\
1- \\
1- \\
1- \\
2- \\
2- \\
2- \\
2- \\
3- \\
4- \\
4- \\
5- \\
6- \\
6- \\
7- \\
7- \\
7-\end{array}$ & $\begin{array}{c}\text { G9985A } \\
\text { T10020C } \\
\text { T2275C } \\
\text { T4399C } \\
\text { G5140A } \\
\text { G3094A } \\
\text { T5892C } \\
\text { G7013A } \\
\text { G9544A } \\
\text { C9537del } \\
\text { T4550C } \\
\text { T5892C } \\
\text { A16183del } \\
\text { G3014A } \\
\text { C15540ins } \\
\text { G2643C } \\
\text { G2916A } \\
\text { A6698del }\end{array}$ & $\begin{array}{c}\text { COIII } \\
\text { tRNAGly } \\
16 S \text { rRNA } \\
\text { tRNAGln } \\
\text { ND2 } \\
16 S \text { rRNA } \\
\text { noncoding } \\
\text { COI } \\
\text { COIII } \\
\text { COIII } \\
\text { ND2 } \\
\text { noncoding } \\
\text { D-loop } \\
16 S \text { rRNA } \\
\text { cyt b } \\
16 S \text { rRNA } \\
16 S \text { rRNA } \\
\text { COI }\end{array}$ & $\begin{array}{c}\text { heteroplasmic (70\%) } \\
\text { heteroplasmic }(60 \%) \\
\text { heteroplasmic (40\%) } \\
\text { homoplasmic } \\
\text { homoplasmic } \\
\text { heteroplasmic (40\%) } \\
\text { homoplasmic } \\
\text { heteroplasmic (50\%) } \\
\text { homoplasmic } \\
\text { homoplasmic } \\
\text { homoplasmic } \\
\text { homoplasmic } \\
\text { homoplasmic } \\
\text { homoplasmic } \\
\text { heteroplasmic (30\%) } \\
\text { heteroplasmic (90\%) } \\
\text { heteroplasmic (50\%) } \\
\text { homoplasmic }\end{array}$ & $\begin{array}{c}\text { Gly-Glu } \\
- \\
- \\
- \\
\text { Ser-Asn } \\
- \\
- \\
\text { silent } \\
\text { Gly-Glu } \\
\text { frameshift } \\
\text { silent } \\
- \\
- \\
- \\
\text { frameshift } \\
- \\
- \\
\text { frameshift }\end{array}$ & $\begin{array}{c}\text { highly conserved } \\
\text { highly conserved } \\
\text { poorly conserved } \\
\text { highly conserved } \\
\text { moderately conserved } \\
- \\
- \\
\text { highly conserved } \\
\text { highly conserved } \\
\text { highly conserved } \\
\text { poorly conserved } \\
- \\
- \\
\text { highly conserved } \\
\text { invariant } \\
\text { highly conserved } \\
\text { highly conserved } \\
\text { highly conserved }\end{array}$ & $\begin{array}{c}\text { not seen } \\
\text { not seen } \\
\text { not seen } \\
\text { not seen } \\
\text { not seen } \\
\text { not seen } \\
\text { not seen } \\
\text { Haplogroup } \mathrm{H}, \mathrm{C} \\
\text { not seen } \\
\text { not seen } \\
\text { not seen } \\
\text { not seen } \\
\text { polymorphism } \\
\text { not seen } \\
\text { not seen } \\
\text { not seen } \\
\text { not seen } \\
\text { not seen }\end{array}$ \\
\hline $3(71 \mathrm{yr})$ & $\begin{array}{l}1+ \\
1- \\
1- \\
1- \\
1- \\
2- \\
2- \\
2- \\
3- \\
3- \\
4- \\
4- \\
5- \\
5- \\
5- \\
5- \\
6- \\
7-\end{array}$ & $\begin{array}{l}\text { T10591C } \\
\text { G1289C } \\
\text { G7053A } \\
\text { G8557A } \\
\text { G9489A } \\
\text { C309del } \\
\text { C9537ins } \\
\text { C16111T } \\
\text { C375ins } \\
\text { T7901C } \\
\text { G943A } \\
\text { T6937C } \\
\text { G4446A } \\
\text { G9543A } \\
\text { G9921A } \\
\text { C14920T } \\
\text { G9544A } \\
\text { G1586A }\end{array}$ & $\begin{array}{c}\text { ND4L } \\
\text { 12S rRNA } \\
\text { COI } \\
\text { ATPase 6 } \\
\text { COIII } \\
\text { D-loop } \\
\text { COIII } \\
\text { D-loop } \\
\text { D-loop } \\
\text { COII } \\
\text { 12S rRNA } \\
\text { COI } \\
\text { tRNA } \\
\text { COIII } \\
\text { COIII } \\
\text { cyt b } \\
\text { COIII } \\
\text { 12S rRNA }\end{array}$ & $\begin{array}{c}\text { homoplasmic } \\
\text { homoplasmic } \\
\text { homoplasmic } \\
\text { homoplasmic } \\
\text { homoplasmic } \\
\text { heteroplasmic (50\%) } \\
\text { homoplasmic } \\
\text { homoplasmic } \\
\text { homoplasmic } \\
\text { homoplasmic } \\
\text { homoplasmic } \\
\text { homoplasmic } \\
\text { heteroplasmic }(60 \%) \\
\text { heteroplasmic }(80 \%) \\
\text { heteroplasmic }(70 \%) \\
\text { heteroplasmic }(70 \%) \\
\text { homoplasmic } \\
\text { heteroplasmic }(60 \%)\end{array}$ & $\begin{array}{c}\text { Phe-Ser } \\
- \\
\text { Gly-TER } \\
\text { Ala-Thr } \\
\text { Ala-Thr } \\
- \\
\text { frameshift } \\
- \\
- \\
\text { Trp-Arg } \\
- \\
\text { Ile-Thr } \\
- \\
\text { Gly-TER } \\
\text { Ala-Thr } \\
\text { silent } \\
\text { Gly-Glu } \\
-\end{array}$ & $\begin{array}{c}\text { highly conserved } \\
\text { poorly conserved } \\
\text { invariant } \\
\text { poorly conserved } \\
\text { poorly conserved } \\
- \\
\text { highly conserved } \\
- \\
- \\
\text { highly conserved } \\
\text { highly conserved } \\
\text { moderately conserved } \\
\text { highly conserved } \\
\text { highly conserved } \\
\text { moderately conserved } \\
\text { moderately conserved } \\
\text { highly conserved } \\
\text { highly conserved }\end{array}$ & $\begin{array}{c}\text { not seen } \\
\text { not seen } \\
\text { not seen } \\
\text { Haplogroup } A, H, I, J \\
\text { not seen } \\
\text { polymorphism } \\
\text { not seen } \\
\text { polymorphism } \\
\text { not seen } \\
\text { not seen } \\
\text { not seen } \\
\text { not seen } \\
\text { not seen } \\
\text { not seen } \\
\text { not seen } \\
\text { not seen } \\
\text { not seen } \\
\text { not seen }\end{array}$ \\
\hline $5(70 y r)$ & $\begin{array}{l}1+ \\
1- \\
2- \\
3- \\
4- \\
5- \\
6-\end{array}$ & $\begin{array}{l}\text { C309ins } \\
\text { G1831A } \\
\text { A4986G } \\
\text { G5164A } \\
\text { T11770C } \\
\text { G14963A } \\
\text { G15756A }\end{array}$ & $\begin{array}{l}\text { D-loop } \\
12 S r R N A \\
N D 2 \\
N D 2 \\
N D 4 \\
\text { cyt b } \\
\text { cyt b }\end{array}$ & $\begin{array}{l}\text { heteroplasmic }(60 \%) \\
\text { heteroplasmic }(30 \%) \\
\text { heteroplasmic }(40 \%) \\
\text { heteroplasmic }(30 \%) \\
\text { heteroplasmic }(30 \%) \\
\text { heteroplasmic }(60 \%) \\
\text { heteroplasmic }(40 \%)\end{array}$ & $\begin{array}{c}- \\
- \\
\text { Thr-Ala } \\
\text { Arg-His } \\
\text { silent } \\
\text { Val-Met } \\
\text { Trp-TER }\end{array}$ & $\begin{array}{l}- \\
\text { moderately conserved } \\
\text { highly conserved } \\
\text { poorly conserved } \\
\text { poorly conserved } \\
\text { highly conserved } \\
\text { highly conserved }\end{array}$ & $\begin{array}{l}\text { polymorphism } \\
\text { not seen } \\
\text { not seen } \\
\text { not seen } \\
\text { not seen } \\
\text { not seen } \\
\text { not seen }\end{array}$ \\
\hline
\end{tabular}

Individual crypts were microdissected and the sequence of the entire mitochondrial genome determined using a two-step amplification strategy (15). For five patients (patients 1-5), we microdissected eight cytochrome $c$ oxidase-deficient (1- to 8-) and four cytochrome $c$ oxidase-normal colonic crypts $(1+$ to $4+)$. The mutations shown represent sequence variants in these individual crypts that were not observed in other crypts from that patient. No mutations were detected in the 12 crypts sequenced from patient 4 (71 years old). Patient 1 had an average of $4.4 \%$ cytochrome $c$ oxidase-deficient crypts; patient 2, 8.9\%; patient 3, 2.8\%; patient 4, 9.67\%; patient 5, 27.9\%. All changes were confirmed by resequencing in either the forward or reverse direction. Levels of mtDNA heteroplasmy are based upon the relative proportion of each genotype shown on the sequencing chromatogram. For mutations affecting mitochondrial structural genes, evolutionary conservation of the affected AA was assessed using the PIR-International Protein Sequence Database (46). Conservation of individual tRNA mutations and rRNA motifs were checked using a mammalian tRNA database (http://mamittRNA.u.strasbg.fr/) and BLAST searches (http://www.ncbi.nlm.nih.gov/Entrez). All sequence variants were further checked using MITOMAP (47) and in a database of 754 human mtDNA coding sequences to assess whether changes were present as polymorphisms in the general population (48). A list of the mtDNA polymorphisms observed in each of the 12 crypts for the five patients is available (49). Abbreviations for the amino acid residues are as follows: Ala, alanine; Arg, arginine; Asn, asparagine; Asp, aspartate; Glu, glutamate; Gly, glycine; His, histidine; Ile, isoleucine; Met, methionine; Phe, phenylalanine; Ser, serine; Thr, threonine; Trp, tryptophan; Val, valine. TER represents termination codon. 


\section{Figure 3}

a

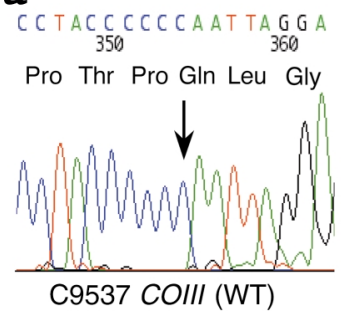

b

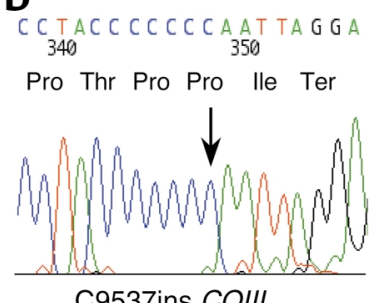

C9537ins COIII
C
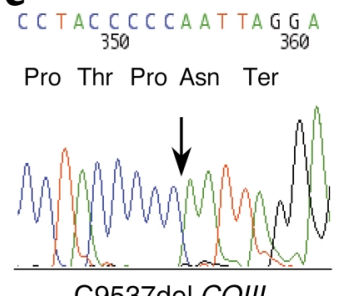

Pro Thr Pro Asn Ter

Examples of frameshift mutations within cytochrome $c$ oxidase structural genes associated with cytochrome $c$ oxidase deficiency. (a) Sequencing electropherogram detailing a region of COIII containing a short, poly-C tract of six residues (nucleotides 9532-9537) amplified from a cytochrome $c$ oxidase positive-reacting colonic crypt. (b) Sequencing of this region in an alternative cytochrome $c$ oxidase-deficient crypt revealed a homoplasmic single nucleotide insertion (C9537ins). The frameshift induced by this insertion creates a premature stop codon predicting the synthesis of a truncated cytochrome $c$ oxidase subunit III polypeptide of 110 amino acids and as such is likely to be the cause of the enzyme defect (20). (c) In another cytochrome $c$ oxidase-deficient colonic crypt, we identified a single C nucleotide deletion within this poly-C tract (C9537del) present at near homoplasmic levels. Similar to the C9537ins mutation, this change also leads to the premature truncation of the cytochrome $c$ oxidase III subunit, resulting in cytochrome $c$ oxidase deficiency. Abbreviations for the amino acid residues are as follows: Asn, asparagine; Gln, glutamine; Gly, glycine; lle, isoleucine; Leu, leucine; Pro, proline; Thr, threonine. Ter represents termination codon.

Through simple probability arguments the theoretical curves are given by $P_{0}=(1-P)^{E}, P_{1}=P_{0} E P /(1-$ $P), P_{2}=(1 / 2) P_{1}(E-1) P /(1-P)$ and $P_{>2}=1-P_{0}-P_{1}-P_{2}$. With these simple parameters we saw the accumulation of colonic crypt cells containing high levels of mutant mtDNA through random genetic drift due to the random partitioning of mitochondrial genotypes during cell division (Figure 4a). The number of cells containing homoplasmic or near-homoplasmic mutants was dependent upon the chosen mutation rate.

By giving each new mtDNA mutation a specific label, we were able to study the number of different mtDNA mutations within each simulated stem cell. Previous work has shown that our singlecell sequencing techniques detect levels of heteroplasmy of more cells based upon experimentally derived parameters ( 9 , 24-26). We studied the effects of a continuous somatic mutation rate on the mtDNA population within 1,000 simulated stem cells over an 80 -year period. The simulation results are well described by simple probability functions. If mutations occur at a rate $R$ per day per genome, then in a total cellular population size of $N$ genomes the number of mutation events $(E)$ that occur by time $t$ is $E=R N t$. The probability $(P)$ of a new mutation undergoing a clonal expansion by random drift is $P=1 / N$. than 30\% for the lesser species (15). We therefore measured the number of different mtDNA mutations at more than $30 \%$ within each colonic crypt stem cell at age 80 years over a range of different mutation rates (Figure $4 \mathrm{~b})$. At lower mutation rates $\left(10^{-6}\right.$ mutations per genome per day) we saw only single clonally expanded mutations in a small percentage $(<10 \%)$ of cells and a high proportion of stem cells containing only wild-type mtDNA. By contrast, at a higher mutation rate $\left(2 \times 10^{-4}\right.$ mutations per genome per day) the vast majority $(>95 \%)$
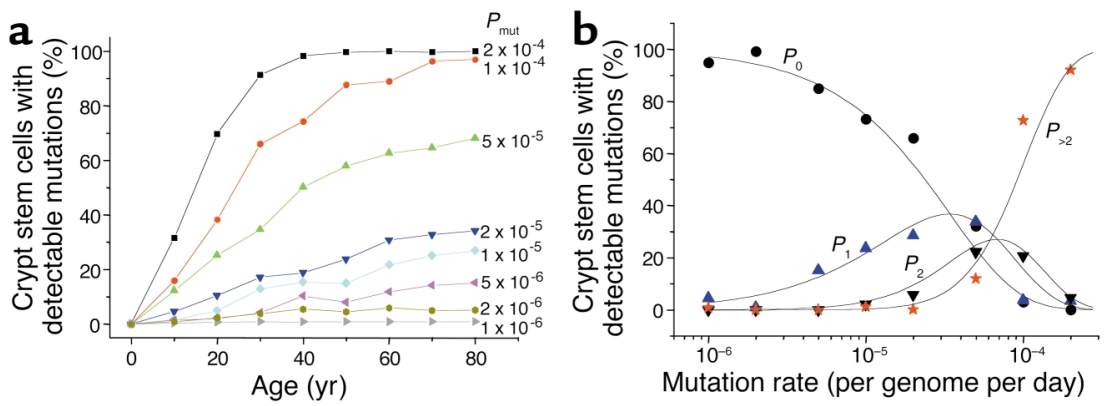

\section{Figure 4}

Mathematical modeling of mitochondrial DNA mutation and replication in colonic crypt stem cells. Simulated cells contained approximately $10,000 \mathrm{mtDNA}$ and divided every 24 hours. Each symbol is the result of 300 (at high mutation rates) to 3,000 (at low mutation rates) independent simulations. (a) The percentage of simulated crypt stem cells containing detectable $(>30 \%)$ mutant mtDNA during a human lifespan. Each curve corresponds to a different mutation rate indicated on the figure. The model predicts that the random partitioning of mitochondrial genomes during crypt cell division will cause random genetic drift and lead to the clonal expansion of somatic mtDNA mutations during human life. (b) The percentage of simulated crypt stem cells containing a detectable amount of mtDNA mutations as a function of the mtDNA mutation rate (circles, no mutations, > 30\%; triangles, one mutation, $>30 \%$; inverted triangles, two mutations, >30\%; asterisk, three or more mutations. The curves represent the theoretical simple probability functions). The model predicts that the mutation rate must be approximately $5 \times 10^{-5}$ per genome per day in order to simultaneously generate crypt stem cells that contain no mutations, and some that have two or more detectable mutations, at age 80 years. Previous simulations demonstrate that the random partitioning of individual genomes during stem cell division will cause random genetic drift and clonal expansion of somatic mtDNA mutations, and the speed of the random drift is dependent upon the frequency of the crypt stem cell divisions. Changing the rate of stem cell division to once per 48 hours did not alter the simulation results. 


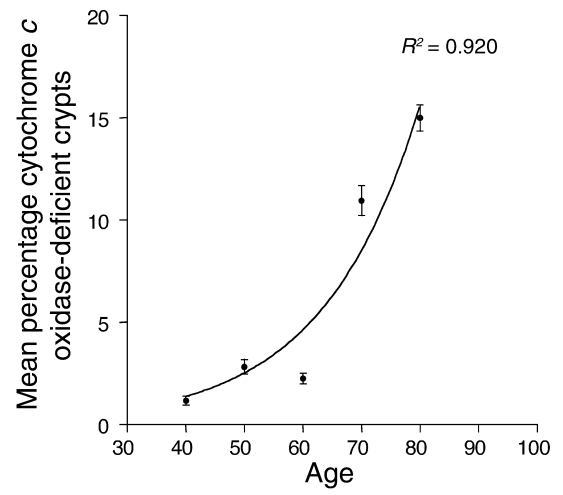

Figure 5

Incidence of cytochrome $c$ oxidase-deficient colonic crypts per decade. Only crypts in which at least $50 \%$ of all cells were cytochrome $c$ oxidase deficient were included. The crypts were counted on at least ten different transverse sections for 28 individual patients. The average value for each patient was included in the mean \pm SEM value given for each decade. The number of patients per decade was 35-44 years, four patients; 45-54 years, seven patients; $55-64$ years, five patients; $65-74$ years, six patients; $75-84$ years, six patients. (See also Table 2.) $R^{2}$ is a measure of the conformation to an exponential increase where 0 represents no association and 1 is a perfect fit.

of stem cells contained three or more clonally expanded mutant species, and very few contained only wildtype mtDNA. Only at intermediate mutation rates $\left(5 \times 10^{-5}\right.$ mutations per genome per day) did we see both single clonally expanded mtDNA mutations and multiple clonally expanded species affecting $10-30 \%$ of the simulated crypt stem cells and a similar number of cells containing only wild-type mtDNA. This has important implications for our understanding of somatic mtDNA mutation. Our data provide the first estimate of the somatic mtDNA mutation rate in humans in vivo of approximately $5 \times 10^{-5}$ mutations per genome per day, corresponding to a rate of 1.10 mutations per site per million years. This is strikingly similar to the pedigreederived mtDNA substitution rates (27) that are consistently higher than mutation rates derived from phylogenetic analysis (28). Moreover, the rate we have derived from the study of colonic crypts is similar to the rate measured for mtDNA $\left(2 \times 10^{-8}\right.$ mutations per site per cell division) in cultured cells in vitro (29) and substantially greater than that of nuclear DNA $\left(6 \times 10^{-11}\right.$ mutations per site per cell division).

\section{Discussion}

We hypothesized that mtDNA mutations may accumulate in stem cells in view of a high mutation rate in the mitochondrial genome and the possibility of accumulation of these mutations by a combination of relaxed replication and random segregation between daughter cells. Our investigations concentrated on colonic crypt stem cells because the progeny of these stem cells can be clearly identified and thus detecting the mutations and the resulting biochemical deficiency would be easier than for many other stem cells. Our investigations show that these stem cells do indeed accumulate mtDNA mutations to high levels and if the mutations involve an important base in either a structural or RNA gene then they can result in a biochemical defect. We have no reason to believe that these findings will be limited to colonic crypt stem cells and thus believe that our observations have implications for other stem cells.

Interestingly, in the cytochrome $c$ oxidase-deficient crypts we detected predominantly mutations in the protein-encoding genes, which are very different from the mutation spectrum we see in patients with mtDNA disease. In our experience of investigating patients with inherited mtDNA defects, the number of mutations involving RNA genes is much greater than the mutations involving structural genes. This may indicate that the more severe phenotype associated with subunit mutations is less compatible with transmission through the germline, an observation in keeping with the relatively rare transmission of mtDNA deletions (30).

In some cytochrome $c$ oxidase-deficient crypts we did not detect mtDNA point mutations, or, if they were present, they were likely to be polymorphic variants rather than pathogenic mutations. This was especially true of patients 4 and 5 , the patients who had the highest number of cytochrome $c$ oxidase-deficient crypts.

\section{Table 2}

Details of patients studied for the presence of cytochrome $c$ oxidase-deficient crypts

\begin{tabular}{|c|c|c|c|}
\hline Age $(y r)$ & $\begin{array}{l}\text { Mean \% cytochrome } c \\
\text { oxidase-deficient crypts }\end{array}$ & SD & $\begin{array}{l}\text { Resection or } \\
\text { colonoscopy }\end{array}$ \\
\hline 36 & 1.23 & 1.01 & Colonoscopy \\
\hline 36 & 0.80 & 0.73 & Colonoscopy \\
\hline 38 & 0.95 & 0.91 & Colonoscopy \\
\hline 38 & 0.20 & 0.36 & Colonoscopy \\
\hline 45 & 2.66 & 1.70 & Colonoscopy \\
\hline 50 & 2.68 & 1.53 & Resection \\
\hline 50 & 3.76 & 0.97 & Colonoscopy \\
\hline 50 & 1.14 & 2.86 & Colonoscopy \\
\hline 53 & 3.40 & 1.17 & Resection \\
\hline 53 & 0.95 & 0.80 & Colonoscopy \\
\hline 54 & 4.99 & 1.34 & Colonoscopy \\
\hline 58 & 0.14 & 0.26 & Resection \\
\hline 58 & 2.08 & 0.58 & Colonoscopy \\
\hline 60 & 2.29 & 1.38 & Resection \\
\hline 62 & 5.40 & 1.17 & Resection \\
\hline 64 & 2.25 & 0.27 & Resection \\
\hline 65 & 1.40 & 1.07 & Resection \\
\hline 67 & 24.40 & 5.17 & Colonoscopy \\
\hline $70^{A}$ & 27.90 & 3.93 & Resection \\
\hline $71^{\mathrm{A}}$ & 2.80 & 1.03 & Resection \\
\hline $71^{A}$ & 9.67 & 1.50 & Resection \\
\hline 74 & 6.30 & 5.87 & Resection \\
\hline 75 & 1.70 & 0.82 & Resection \\
\hline $75^{A}$ & 4.40 & 1.07 & Resection \\
\hline 75 & 9.00 & 2.21 & Resection \\
\hline $76^{A}$ & 8.90 & 1.60 & Resection \\
\hline 78 & 2.17 & 2.54 & Colonoscopy \\
\hline 80 & 33.90 & 2.81 & Resection \\
\hline
\end{tabular}

AThe patients in which detailed sequencing studies were performed. 
There are several possibilities to explain the cytochrome $c$ oxidase deficiency in these crypts, including mtDNA deletions that were not detected by our realtime assay or multiple mtDNA point mutations present below the limit of detection by automated sequencing. A further possibility would be mutations of nuclear genes. Our immunocytochemical studies revealed an absence of cytochrome $c$ oxidase subunits I and II (encoded by the mitochondrial genome) and partial deficiency of subunit IV (encoded by the nuclear genome). There was no difference in the immunocytochemical reactions between those patients with high levels of mtDNA mutations and those (patient 4 and 5) in which the mtDNA mutations were not detected. These results could imply involvement of either the mitochondrial or nuclear genome. Nuclear gene mutations causing systemic cytochrome $c$ oxidase deficiency are increasingly being recognized and may involve a nuclear-encoded cytochrome $c$ oxidase structural subunit (although no mutations have been described to date) (31), a cytochrome $c$ oxidase assembly factor, or a protein involved in mtDNA maintenance (32-37). If, indeed, the cytochrome $c$ oxidase deficiency is due to a nuclear gene defect, it is uncertain as to whether this involves a single gene or several different genes, with each deficient crypt due to a new mutation. It is recognized that nuclear gene defects can cause a mosaic picture of cytochrome $c$ oxidase deficiency and therefore the involvement of different crypts does not differentiate between the possibilities of a mitochondrial and nuclear gene involvement (38). We suspect that a nuclear gene defect causing either mtDNA depletion or multiple deletions would have been detected by our real-time assay, which not only detects deletions but also quantifies mtDNA copy number (14). We failed, however, to detect any difference in copy number between cytochrome $c$ oxidase-deficient and cytochrome $c$ oxidase-normal crypts in any of our patients. Another possibility is that the observation of low cytochrome $c$ oxidase activity relates to a downregulation of the respiratory chain activity in response to the colonic tumor. This we think is unlikely because the cytochrome $c$ oxidase-deficient crypts were also observed in patients without tumors, and they occur in the presence of normal SDH activity (Figure 1). Finally, if nuclear genetic defects (or altered regulation) are the cause of the cytochrome $c$ oxidase deficiency in patient 4 and 5 , what then could be the contribution of the nuclear genome to the cytochrome $c$ oxidase-deficient crypts in our other patients? At this stage we can only speculate that we believe that the mtDNA defect is pathogenic in some crypts, but further studies are required to determine if the mutations are sufficient alone to generate the biochemical defect.

What then is the significance of our observations for mitochondrial genetics and stem cell biology? Our observations highlight how frequently these mutations occur and, when present, that they can accumulate to high levels, sufficient, we believe, to cause a biochemical defect. The observed mutation load in these stem cells is high; we sequenced the complete mitochondrial genome in 60 crypts and detected a total of 59 different mtDNA point mutations. In addition, there is likely to have been a significant number of mtDNA mutations present within these stem cells that were not detected. Automated fluorescent-sequencing techniques and real-time PCR will only detect moderate levels of a heteroplasmic change ( $>25 \%$ and $>40 \%$, respectively) $(14,39$ ), and lowlevel heteroplasmy would be missed. If a significant number of stem cells accumulate mutations, it becomes clear that within an individual there will be a mixture of mutations, which may influence tissue function.

Our studies have shown that mtDNA mutations accumulate in cytochrome $c$ oxidase-deficient crypts, and these crypts show an age-related increase in their number (Figure 5 and Table 2). These studies also represent the first description of pathogenic mtDNA mutations in stem cells with human aging. These observations support a role for mtDNA mutations in the aging process, which until now has been based mainly on an age-related accumulation of mtDNA mutations in postmitotic cells. Current understanding indicates that aging is caused by accumulation of stochastic molecular and cellular damage $(40,41)$, and there is evidence from studies in mice that functional impairment of intestinal stem cells occurs with age and is associated with an altered DNA damage response (42). The heterogeneous nature of such stochastic damage at the cellular level makes its detection more difficult and is fully consistent with the diversity we have observed. While our observations are in the colon, we believe they raise important questions about the wider role of mtDNA mutations in stem cell aging.

Our findings are also relevant to reports of mtDNA mutations in colon (21) and other forms of cancer (43). The presence of mtDNA mutations within the colonic crypt stem cells suggests that the mutations are present prior to the development of the colon cancer. Thus, mtDNA mutations in other cancers suggest that these mutations might also originate in the stem cells in these tissues. It is as yet uncertain whether the mtDNA mutation and its associated biochemical defect are involved in the development of malignancy. There is a precedent, however, in that defects of oxidative metabolism caused by nuclear mutations may lead to the development of tumors $(44,45)$.

\section{Acknowledgments}

We are grateful to N. Howell for access to the MitoKor database and J. Elson for help with interpretation of sequence analysis. We would also like to thank R.N. Lightowlers, J. Mathers, E. Williams, and J. Burn for helpful discussions and provision of normal colonic material. These studies were supported by the Wellcome Trust, the Medical Research Council, and Cancer Research UK. A. Gospel was in receipt of a bursary from the PPP Foundation. Finally, we are grateful for the insightful comments of the anonymous reviewers of this manuscript, some of which have contributed to the discussion. 
1. Chinnery, P.F., et al. 2000. The epidemiology of pathogenic mitochondrial DNA mutations. Ann. Neurol. 48:188-193.

2. Lightowlers, R.N., Chinnery, P.F., Turnbull, D.M., and Howell, N. 1997. Mammalian mitochondrial genetics: heredity, heteroplasmy and disease. Trends Genet. 13:450-455.

3. Sciacco, M., Bonilla, E., Schon, E.A., DiMauro, S., and Moraes, C.T. 1994 Distribution of wild-type and common deletion forms of mtDNA in normal and respiration-deficient muscle fibers from patients with mitochondrial myopathy. Hum. Mol. Genet. 3:13-19.

4. Brierley, E.J., Johnson, M.A., Lightowlers, R.N., James, O.F., and Turnbull, D.M. 1998. Role of mitochondrial DNA mutations in human aging: implications for the central nervous system and muscle. Ann. Neurol. 43:217-223.

5. Cortopassi, G., and Arnheim, N. 1990. Detection of specific mitochondrial DNA deletion in tissues of older humans. Nucleic Acids Res. 275:169-180.

6. Michikawa, Y., Mazzucchelli, F., Bresolin, N., Scarlato, G., and Attardi, G. 1999. Aging-dependent large accumulation of point mutations in the human mtDNA control region for replication. Science. 286:774-779.

7. Murdock, D.G., Christacos, N.C., and Wallace, D.C. 2000. The age-related accumulation of a mitochondrial DNA control region mutation in muscle, but not brain, detected by a sensitive PNA-directed PCR clamping based method. Nucleic Acids Res. 28:4350-4355.

8. Coller, H.A., et al. 2001. High frequency of homoplasmic mitochondrial DNA mutations in human tumors can be explained without selection. Nat. Genet. 28:147-150.

9. Chinnery, P.F., and Samuels, D.C. 1999. Relaxed replication of mtDNA a model with implications for the expression of disease. Am. J. Hum. Genet. 64:1158-1165.

10. Nekhaeva, E., et al. 2002. Clonally expanded mtDNA point mutations are abundant in individual cells of human tissues. Proc. Natl. Acad. Sci. U. S. A. 99:5521-5526.

11. Bach, S.P., Renehan, A.G., and Potten, C.S. 2000. Stem cells: the intestinal stem cell as a paradigm. Carcinogenesis. 21:469-476.

12. Schmidt, G.H., Winton, D.J., and Ponder, B.A. 1988. Development of the pattern of cell renewal in the crypt-villus unit of chimaeric mouse small intestine. Development. 103:785-790.

13. Yatabe, Y., Tavare, S., and Shibata, D. 2001. Investigating stem cells in human colon by using methylation patterns. Proc. Natl. Acad. Sci. U. S. A. 98:10839-10844.

14. He, L., et al. 2002. Detection and quantification of mitochondrial DNA deletions in individual cells by real-time PCR. Nucleic Acids Res. [serial online]. 30:e68. http://nar.oupjournals.org/cgi/content/full/30/14/e68

15. Taylor, R.W., Taylor, G.A., Durham, S.E., and Turnbull, D.M. 2001. The determination of complete human mitochondrial DNA sequences in single cells: implications for the study of somatic mitochondrial DNA point mutations. Nucleic Acids Res. [serial online]. 29:e74. http:// nar.oupjournals.org/cgi/content/full/29/15/e74.

16. Hirano, M., et al. 1997. Apparent mtDNA hetzeroplasmy in Alzheimer's disease patients and normals due to PCR amplification of nuclear-embedded mtDNA pseudogenes. Proc. Natl. Acad. Sci. U. S. A. 94:14894-14899.

17. Johnson, M.A., Bindoff, L.A., and Turnbull, D.M. 1993. Cytochrome $c$ oxidase activity in single muscle fibers: assay techniques and diagnostic applications. Ann. Neurol. 33:28-35.

18. Andrews, R.M., et al. 1999. Reanalysis and revision of the Cambridge Reference Sequence for human mitochondrial DNA. Nat. Genet. 23:147. (Letter)

19. Andreu, A.L., et al. 1999. Exercise intolerance due to mutations in the cytochrome b gene of mitochondrial DNA. N. Engl. J. Med. 341:1037-1044.

20. Tiranti, V., et al. 2000. A novel frameshift mutation of the mtDNA COIII gene leads to impaired assembly of cytochrome $c$ oxidase in a patient affected by Leigh-like syndrome. Hum. Mol. Genet. 9:2733-2742.

21. Polyak, K., et al. 1998. Somatic mutations of the mitochondrial genome in human colorectal tumours. Nat. Genet. 20:291-293.

22. Cadenas, E., and Davies, K.J. 2000. Mitochondrial free radical generation, oxidative stress, and aging(1). Free Radic. Biol. Med. 29:222-230.

23. Jenuth, J.P., Peterson, A.C., and Shoubridge, E.A. 1997. Tissue-specific selection for different mtDNA genotypes in heteroplasmic mice. Nat. Genet. 16:93-95.
24. Shadel, G.S., and Clayton, D.A. 1997. Mitochondrial DNA maintenance in vertebrates. Annu. Rev. Biochem. 66:409-435.

25. Gross, N.J., Getz, G.S., and Rabinowitz, M. 1969. Apparent turnover of mitochondrial deoxyribonucleic acid and mitochondrial phospholipids in the tissues of the rat. J. Biol. Chem. 244:1552-1562.

26. Elson, J.L., Samuels, D.C., Turnbull, D.M., and Chinnery, P.F. 2001. Random intracellular drift explains the clonal expansion of mitochondrial DNA mutations with age. Am. J. Hum. Genet. 68:802-806.

27. Howell, N., Kubacka, I., and Mackey, D.A. 1996. How rapidly does the human mitochondrial genome evolve? Am. J. Hum. Genet. 59:501-509.

28. Heyer, E., et al. 2001. Phylogenetic and familial estimates of mitochondrial substitution rates: study of control region mutations in deep-rooting pedigrees. Am. J. Hum. Genet. 69:1113-1126.

29. Khrapko, K., et al. 1997. Mitochondrial mutational spectra in human cells and tissues. Proc. Natl. Acad. Sci. U. S. A. 94:13798-13803.

30. Shanske, S., et al. 2002. Identical mitochondrial DNA deletion in a woman with ocular myopathy and in her son with Pearson syndrome. Am. J. Hum. Genet. 71:679-683.

31. Adams, P.L., Lightowlers, R.N., and Turnbull, D.M. 1997. Molecular analysis of cytochrome $c$ oxidase deficiency in Leigh's syndrome. Ann. Neurol. 41:268-270.

32. Papadopoulou, L.C., et al. 1999. Fatal infantile cardioencephalomyopathy with $\mathrm{COX}$ deficiency and mutations in $\mathrm{SCO} 2$, a COX assembly gene. Nat. Genet. 23:333-337.

33. Tiranti, V., et al. 1998. Mutations of SURF-1 in Leigh disease associated with cytochrome $c$ oxidase deficiency. Am. J. Hum. Genet. 63:1609-1621.

34. Zhu, Z., et al. 1998. SURF1, encoding a factor involved in the biogenesis of cytochrome $c$ oxidase, is mutated in Leigh syndrome. Nat. Genet. 20:337-343.

35. Mootha, V.K., et al. 2003. Identification of a gene causing human cytochrome $c$ oxidase deficiency by integrative genomics. Proc. Natl. Acad. Sci.U.S. A. 100:605-610.

36. Antonicka, H., et al. 2003. Mutations in COX15 produce a defect in the mitochondrial heme biosynthetic pathway, causing early-onset fatal hypertrophic cardiomyopathy. Am. J. Hum. Genet. 72:101-114.

37. Valnot, I., et al. 2000. Mutations of the SCO1 gene in mitochondrial cytochrome $c$ oxidase deficiency with neonatal-onset hepatic failure and encephalopathy. Am. J. Hum. Genet. 67:1104-1109.

38. Rahman, S., et al. 2000. Cytochrome oxidase immunohistochemistry: clues for genetic mechanisms. Brain. 123:591-600.

39. Herrnstadt, C., et al. 2002. A high frequency of mtDNA polymorphisms in HeLa cell sublines. Mutat. Res. 501:19-28.

40. Kirkwood, T.B., and Austad, S.N. 2000. Why do we age? Nature. 408:233-238

41. Herndon, L.A., et al. 2002. Stochastic and genetic factors influence tissue-specific decline in ageing C. elegans. Nature. 419:808-814.

42. Martin, K., Potten, C.S., and Kirkwood, T.B. 2000. Age-related changes in irradiation-induced apoptosis and expression of p21 and p53 in crypt stem cells of murine intestine. Ann. N. Y. Acad. Sci. 908:315-318.

43. Fliss, M.S., et al. 2000. Facile detection of mitochondrial DNA mutations in tumors and bodily fluids. Science. 287:2017-2019.

44. Neumann, H.P., et al. 2002. Germ-line mutations in nonsyndromic pheochromocytoma. N. Engl. J. Med. 346:1459-1466.

45. Tomlinson, I.P., et al. 2002. Germline mutations in FH predispose to dominantly inherited uterine fibroids, skin leiomyomata and papillary renal cell cancer. Nat. Genet. 30:406-410.

46. Wu, C.H., et al. 2002. The Protein Information Resource: an integrated public resource of functional annotation of proteins. Nucleic Acids Res. 30:35-37.

47. MITOMAP: A human mitochondrial genome database. http://www.mitomap.org.

48. Herrnstadt, C., et al. 2002. Reduced-median-network analysis of complete mitochondrial DNA coding-region sequences for the major African, Asian, and European haplogroups. Am. J. Hum. Genet. 70:1152-1171.

49. Taylor, R.W., et al. 2003. mtDNA polymorphisms in patient colonic crypts. http://www.ncl.ac.uk/nnp/nnp/research/mnrg/mtdnaage/colon.htm. 